\title{
Multi-layered composite detectors for neutron detection
}

\author{
V.D.Ryzhikov, B.V.Grinyov, A.Yu.Boyarintsev, V.S.Tinkova, \\ V.V.Maksymchuk, A.G.Yakubovskaya, I.A.Tupitsyna
}

\author{
Institute for Scintillation Materials, STC "Institute for Single Crystals", \\ National Academy of Sciences of Ukraine, \\ 60 Nauky Ave., 61072 Kharkiv, Ukraine
}

\author{
Received July 7, 2017
}

The paper considers the influence of manufacturing technological features of composite scintillators with optimal scintillation characteristics based on heavy-oxide crushed single crystals for ZEBRA-detectors making for fast neutrons registration. It has been shown that fast neutrons registration efficiency by multi-layered ZEBRA-detectors based on crushed $\mathrm{Bi}_{4} \mathrm{Ge}_{3} \mathrm{O}_{12}, \mathrm{Gd}_{2} \mathrm{SiO}_{5}: \mathrm{Ce}$ and $\mathrm{ZnWO}_{4}$ crystals achieved the value about $50 \%$. Sensitivity of ZEBRA-detectors with size of $100 \times 100 \times 41 \mathrm{~mm}^{3}$ is comparable to sensitivity of ${ }^{3} \mathrm{He}$ counter with moderator. $\mathrm{ZnWO}_{4}$ powder obtained by solid state synthesis is proposed as an alternative filler to instead of crushed crystal powders for scintillation composite. Results of technical detection efficiency and sensitivity measurements for fast neutrons (sources $\mathrm{Pu}-\mathrm{Be}$ and ${ }^{252} \mathrm{Cf}$ ) showed that detection efficiency of ZEBRA-detector based on synthesized scintillation $\mathrm{ZnWO}_{4}$ powder is comparable with detector based on crushed $\mathrm{ZnWO}_{4}$ single crystal of the same size. Qualitative explanations for abnormal high sensitivity of multi-layered composite detectors are presented. ZEBRA-detector is promising for application in the field of homeland security and nuclear safeguards.

Keywords: fast neutrons measurements, inelastic and resonant neutron scattering, radiation detectors, multi-layered scintillation detectors, nuclear safeguard, ${ }^{3} \mathrm{He}$ alternative.

Рассмотрено влияние технологических особенностей изготовления композиционных сцинтилляторов на основе размолотых тяжелых оксидных кристаллов для использования в нейтронных детекторах ЗЕБРА. Показано, что әффективность регистрации быстрых нейтронов многослойными детекторами ЗЕБРА на основе размолотых монокристаллов $\mathrm{Bi}_{4} \mathrm{Ge}_{3} \mathrm{O}_{12}$, $\mathrm{Gd}_{2} \mathrm{SiO}_{5}: \mathrm{Ce}$ и $\mathrm{ZnWO}_{4}$ достигает $50 \%$. Чувствительность таких детекторов размером $100 \times 100 \times 41$ мм $^{3}$ сравнима с чувствительностью ${ }^{3}$ Не счетчиков с замедлителями. Порошок $\mathrm{ZnWO}_{4}$, полученный методом твердофазного синтеза, предложен в качестве альтернативного наполнителя сцинтилляционного композита вместо размолотых кристаллов. Результаты измерений технической эффективности регистрации и чувствительности к быстрым нейтронам (источники $\mathrm{Pu}-\mathrm{Be}$ и ${ }^{252} \mathrm{Cf}$ ) показали, что детектор ЗЕБРА на основе синтезированного сцинтилляционного порошка $\mathrm{ZnWO}_{4}$ обладает әффективностью регистрации на уровне детектора на основе размолотого монокристалла $\mathrm{ZnWO}_{4}$. Приведено качественное объяснение аномально высокой чувствительности многослойных композитных детекторов. Показано, что детекторы ЗЕБРА перспективны для применения в области ядерной безопасности.

Багатошарові композиційні детектори для реєстрації нейтронів. В.Д.Рижиков, Б.В.Гриньов, А.Ю.Бояринцев, В.С.Тінькова, В.В.Максимчук, Г.Г.Якубовська, ІА.Тупіцина.

Розглянуто вплив технологічних особливостей виготовлення композиційних сцинтиляторів на основі розмелених важких оксидних кристалів для використання у нейтронних детекторах ЗЕБРА. Показано, що ефективність реєстрації швидких нейтронів 
багатошаровими детекторами ЗЕБРА на основі розмелених монокристалів $\mathrm{Bi}_{4} \mathrm{Ge}_{3} \mathrm{O}_{12}$, $\mathrm{Gd}_{2} \mathrm{SiO}_{5}: \mathrm{Ce}$ та $\mathrm{ZnWO}_{4}$ сягає $50 \%$. Чутливість таких детекторів розміром $100 \times 100 \times 41$ мм $^{3}$ порівняна 3 чутливістю ${ }^{3}$ Не лічильників зі сповільнювачами. Запропоновано порошок $\mathrm{ZnWO}_{4}$, отриманий методом твердофазного синтезу, в якості альтернативного наповнювача сцинтиляційного композиту замість розмелених кристалів. Результати вимірювань технічної ефективності реєстрації та чутливості до швидких нейтронів (джерела Pu-Be та ${ }^{252} \mathrm{Cf}$ ) показали, що детектор ЗЕБРА на основі синтезованого сцинтиляційного порошку $\mathrm{ZnWO}_{4}$ має ефективність реєстрації на рівні детектора на основі розмеленого монокристала $\mathrm{ZnWO}_{4}$. Наведено якісне пояснення аномально високої чутливості багатошарових композитних детекторів. Показано, що детектори ЗЕБРА перспективні для застосування в галузі ядерної безпеки.

\section{Introduction}

The solution of nuclear terrorism problem requires special devices for detection of nuclear materials, in particular, neutron fluxes coming from radioactive substances. Traditionally, ${ }^{3} \mathrm{He}$ counters used for thermal neutrons detection. Massive plastic blocks usage for fast neutron detection is necessary for fast neutrons moderation to thermal energies. As a result, the mass of such detector could reach up to $200 \mathrm{~kg}$ and more, with height up to 3 meters, but herewith the detection efficiency of fast neutrons does not exceed 10-15\% due to double transformation of energy.

Therefore, today much attention is paid to design large area portal monitors for fast neutrons detection as an alternative detectors to ${ }^{3} \mathrm{He}$ technologies in security systems application. At present time the majority of developments such as detectors based on ${ }^{10} \mathrm{~B}$ $[1,2]$, counters with gas $\mathrm{BF}_{3}$ or based on carbide bore [3], the $4 \mathrm{H}-\mathrm{SiC}$ Schottky detectors [4], detectors based on scintillation plastic [5], fast neutron scintillation detectors based on $\mathrm{ZnS}(\mathrm{Ag}) \mathrm{LLiF}$ [6], hybrid detectors consisting of BC501A liquid scintillator and $\mathrm{BC} 702$ scintillator [7], detectors based on scintillation granules surrounded by plastic fibers [8] and etc., have detection efficiency of fast neutron about $10 \%$.

For the first time, high efficiency of fast neutron detection (up to $50 \%$ ) was demonstrated in [9-11] using the detectors based on heavy-oxide $\mathrm{Bi}_{4} \mathrm{Ge}_{3} \mathrm{O}_{12}(\mathrm{BGO}), \mathrm{Gd}_{2} \mathrm{SiO}_{5}: \mathrm{Ce}$ (GSO(Ce)), $\quad \mathrm{ZnWO}_{4} \quad$ (ZWO) and $\mathrm{CdWO}_{4}$ (CWO) large $(\varnothing 40 \times 80 \mathrm{~mm})$ single crystals. The measured sensitivity of this detection system is comparable with the sensitivity of ${ }^{3} \mathrm{He}$-counters. It has been shown in [11] that the $\mathrm{GSO}(\mathrm{Ce})$ using with plastic moderator allowed to achieve fast and thermal neutrons detection efficiency about $90 \%$.

At last time the composite scintillation materials provoke the scientists' interest [12]. Such materials allow to avoid size limitation, to achieve the homogeneity of functional characteristics through the area and to simplify manufacturing technology.

Thus, we designed an original multi-layered detector which consist of different scintillation composite materials and plastic layers and compared their parameters to crystal detectors [13].

The goal of this work is optimization of manufacturing process of detectors based on heavy-oxide scintillators for neutrons registration.

\section{Experimental}

The ZEBRA-detectors consist of alternating optically coupled layers of composite scintillator and plastic plates used as a light guide. The composite layer consists of a binder (heat-resistant low molecular silicone rubber) and dispersed scintillation filler. Crushed oxide crystals powders $\left(\mathrm{Bi}_{4} \mathrm{Ge}_{3} \mathrm{O}_{12}\right.$, $\mathrm{Gd}_{2} \mathrm{SiO}_{5}: \mathrm{Ce}, \mathrm{ZnWO}_{4}$ ) were used as a filler. The grinding was carried out with laboratory mechanical mortar Retch RM 200, following fractionation was carried out with vibratory sieve Retch AS 200. Sieves with cell size of $80 \mu \mathrm{m}, 100 \mu, 140 \mu \mathrm{m}, 200 \mu \mathrm{m}$, $250 \mu \mathrm{m}$ were used. Besides, $\mathrm{ZnWO}_{4}$ powder obtained by solid state synthesis was used as a filler. The $\mathrm{ZnO}$ and $\mathrm{WO}_{3}$ were used as a raw material, more details of synthesis were described in [14].

The light output measurements of composite samples (composite scintillation layers) were carried out in the current mode with Si-photodiode, X-ray source was IRI $(U \alpha=100 \mathrm{keV}, I \alpha=1 \mathrm{~mA})$.

The measurements of obtained ZEBRAdetectors sensitivity and registration efficiency were carried out in the counting mode with neutron sources ${ }^{239} \mathrm{Pu}-\mathrm{Be}$ with neutron flux of $0.95 \cdot 10^{5}$ (flux density per $S$ $=100 \mathrm{~cm}-0.76 \mathrm{n} / \mathrm{s} \cdot \mathrm{cm}^{2}$ ) and ${ }^{252} \mathrm{Cf}$ source with neutron flux $2.35 \cdot 10^{6}$ (flux density per $S=100 \mathrm{~cm}-1.7 \mathrm{n} / \mathrm{s} \cdot \mathrm{cm}^{2}$ ). The energy of both sources does not exceed $1 \mathrm{MeV}$. The measurement errors were about $3 \%$. The 


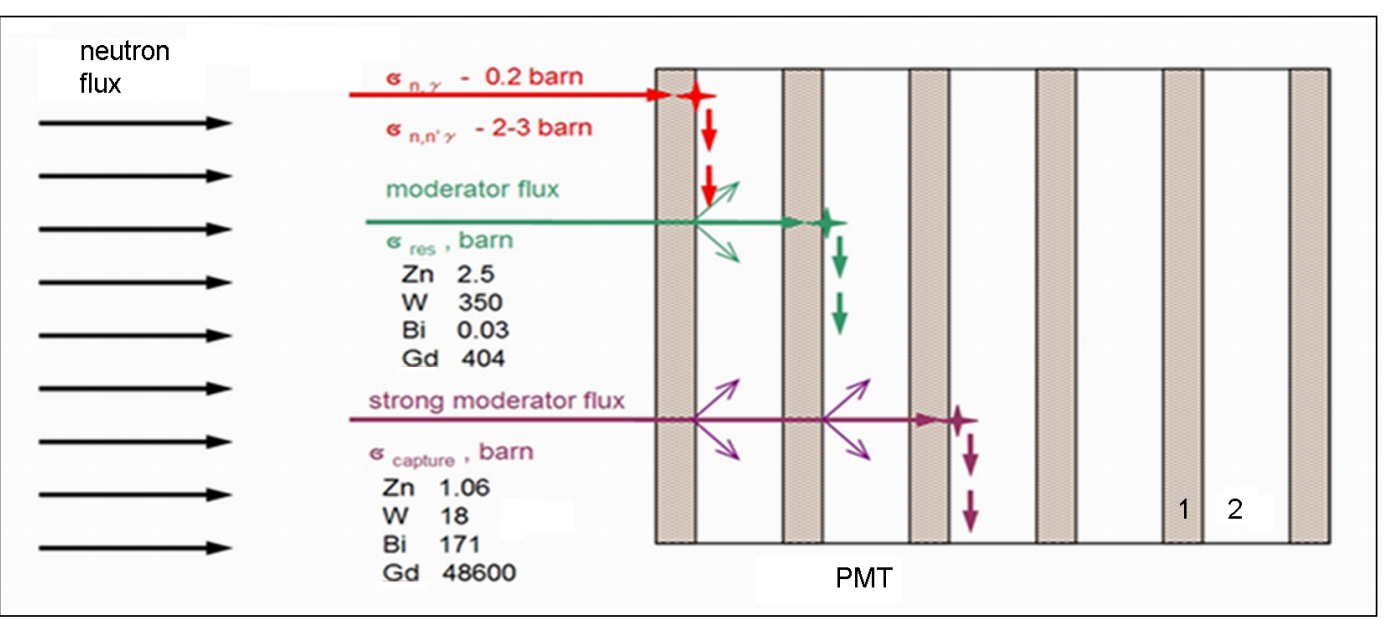

Fig. 1. Design and operation scheme of multi-layered composite detector (optional): 1- active layer of composite scintillator; 2 - passive layer of light-conducting plastic.

apparatus general design and additional details of experiment was described in [11, 16-18]. The sensitive areas of the detectors under irradiation by neutron flux from the side (i.e., normally to the plates) were $16 \mathrm{~cm}^{2}, 40 \mathrm{~cm}^{2}$ and $100 \mathrm{~cm}^{2}$ (Fig. 1).

\section{Results and discussion}

The scintillation response of ZEBRA-detector during neutron registration testing is significantly depends of detector construction (in particular, of irradiated area) and of light output value of composite layers. For the making of composite scintillators (active layers) with optimal scintillation parameters we considered the following technological features: the size of scintillators granules and the filler-binder ratio. Scintillation characteristics of the samples were controlled by measurement of technical light output under X-ray excitation. The irradiated area of tested detectors was $40 \times 40 \mathrm{~mm}^{2}$, $40 \times 100 \mathrm{~mm}^{2}$ and $100 \times 100 \mathrm{~mm}^{2}$.

3.1 ZEBRA-detectors based on heavyoxide crushed crystals

The crushed crystals (GSO(Ce) and ZWO) were divided into several fractions with following granule sizes: 140-280 $\mu \mathrm{m}, 100-$ $140 \mu \mathrm{m}, 80-100 \mu \mathrm{m}$ and less than $100 \mu \mathrm{m}$. Each of them was used as a filler for making the composite samples with thickness of $1 \mathrm{~mm}$. The quantity of filler in samples was $45-50$ wt. $\%$. The light output values of obtained composites are presented in Table 1 . $\mathrm{ZnWO}_{4}$ single crystal $\left(10 \times 10 \times 1 \mathrm{~mm}^{3}\right)$ was chosen as a reference. Light output value decrease with reducing of filler granules size. The light output measurements used $\mathrm{X}$-ray irradiation with energy up to
Table 1. Light output values of the composites based on different fraction of crushed $\mathrm{ZnWO}_{4}$ and $\mathrm{Gd}_{2} \mathrm{SiO}_{5}: \mathrm{Ce}$ single crystals

\begin{tabular}{||c|c|c||}
\hline \hline No. & Samples/fraction, $\mu \mathrm{m}$ & Light output, \% \\
\hline \multicolumn{2}{|c||}{ ZnWO $_{4}$} \\
2 & ZnWO $_{4}$ crystal & 100 \\
3 & $\varnothing<80$ & 65 \\
4 & $80-100$ & 72 \\
5 & $100-140$ & 144 \\
6 & $140-280$ & 270 \\
\multicolumn{3}{|c|}{ as-crushed $_{2}$ SiO $_{5}: \mathrm{Ce}$} \\
7 & $\varnothing<80$ & 280 \\
\hline 8 & $80-100$ & 43 \\
10 & $100-140$ & 54 \\
\hline
\end{tabular}

$100 \mathrm{keV}$ were carried out. Zinc tungstate and gadolinium silicate are compounds with high density $\left(7.9 \mathrm{~g} / \mathrm{cm}^{3}\right.$ and $6.7 \mathrm{~g} / \mathrm{cm}^{3}$, respectively). The layer thickness of these materials absorbing $95 \%$ X-ray irradiation with such energies is about $0.5-1.0 \mathrm{~mm}$. This explains the higher light output values of samples based on large filler granules. Besides, low light output value of sample based on small sized granules can be explained by scattering on filler particles that caused to low light collection factor.

For samples based on the as-crushed powders (without fractionation) we can observe the highest light output value. Similar effect was described in [19-21]. Filler of such samples has wide distribution of particle 
Table 2. The functional parameters of composite detectors based on different crushed crystals comparable with $\mathrm{CdWO}_{4}$ single crystal and ${ }^{3} \mathrm{He}$ counter (radiative source $-{ }^{252} \mathrm{Cf}$ )

\begin{tabular}{|c|c|c|c|c|}
\hline Composite scintillator & Size, $\mathrm{mm}^{3}$ & $\begin{array}{c}\text { Neutron flux, } \\
\text { nps } \cdot \mathrm{cm}^{-2}\end{array}$ & $\begin{array}{l}\text { Sensitivity, } \eta \text {, } \\
\mathrm{cps} / \mathrm{nps} \cdot \mathrm{cm}^{-2}\end{array}$ & Efficiency, $\varepsilon, \%$ \\
\hline${ }^{3} \mathrm{He}$ counter + moderator & $S=4000 \mathrm{~cm}^{2}$ & - & 48 & 1.2 \\
\hline Crystal $\mathrm{CdWO}_{4}$ & $\varnothing 63 \times 100$ & 7.54 & 23 & 53 \\
\hline BGO-ZEBRA & $40 \times 40 \times 41$ & 3.85 & 6.4 & 40 \\
\hline ZWO-ZEBRA & $40 \times 40 \times 41$ & 3.85 & 8.8 & 55 \\
\hline GSO(Ce)-ZEBRA & $40 \times 40 \times 41$ & 3.85 & 7.8 & 49 \\
\hline BGO-ZEBRA & $100 \times 40 \times 41$ & 1.70 & 16 & 40 \\
\hline ZWO-ZEBRA & $100 \times 40 \times 41$ & 1.70 & 16.4 & 45 \\
\hline GSO(Ce)-ZEBRA & $100 \times 40 \times 41$ & 1.70 & 19.6 & 50 \\
\hline BGO-ZEBRA & $100 \times 100 \times 41$ & 1.08 & 40 & 40 \\
\hline ZWO-ZEBRA & $100 \times 100 \times 41$ & 1.08 & 41 & 45 \\
\hline GSO(Ce)-ZEBRA & $100 \times 100 \times 41$ & 1.08 & 51 & 61 \\
\hline
\end{tabular}

sizes. During the polymerization, large granules settle down due to gravitation. There is still free space between the large particles that is filled with polymer binder that working as a light guide. The smallest particles stay on the top of the sample and forming dense layer that working as a diffusion reflector. As a result light collecting conditions are improved and the light output value is increased.

ZEBRA-detectors based on different scintillation crystals (BGO, GSO(Ce), ZWO) were made. The sizes of ZEBRA-detectors were $40 \times 40 \times 41 \mathrm{~mm}^{3}, 100 \times 40 \times 41 \mathrm{~mm}^{3}$ and $100 \times 100 \times 41 \mathrm{~mm}^{3}$. General view of last one is shown on Fig. 2. Total thickness of scintillation composite layers for all detectors was $6 \mathrm{~mm}$ (6 layers with thickness of $1 \mathrm{~mm})$. Total thickness of plastic panels was $35 \mathrm{~mm}$ (7 layers with thickness of $5 \mathrm{~mm}$ ). The external surface of the detectors is covered by a diffuse light reflecting coating, except for one facet connected to the photoreceiving device (photomultiplier (PMT)) in conditions of optical contact and spectral matching.

Measurement results of technical efficiency and sensitivity of fast neutron detection by multi-layered composite ZEBRA-detector based on the heavy-oxide crushed crystals are shown in the Table 2 .

Data of Table 2 show that within measurement errors the fast neutron detection efficiency independents on the area of the plates. The detection efficiency of fast neutron multi-layered composite ZEBRA-detectors based on ZWO and $\mathrm{GSO}(\mathrm{Ce})$ is compa- rable to detection efficiency of detector based on $\mathrm{CdWO}_{4}$ single crystal obtained by Czochralski method [22]. Sensitivity of ZWO-ZEBRA detector rises with increase of detectors size from $40 \times 40 \times 41 \mathrm{~mm}^{3}$ to $100 \times 100 \times 41 \mathrm{~mm}^{3}$ and exceeds in two times sensitivity of detector based on $\mathrm{CdWO}_{4}$ single crystal and comparable with sensitivity of ${ }^{3} \mathrm{He}$ counter + moderator.

\subsection{ZEBRA-detector based on $\mathrm{ZnWO}_{4}$} powders obtained by solid state synthesis

We propose to use $\mathrm{ZnWO}_{4}$ powder obtained without the single crystal growth stage in order to reduce the cost of ZEBRA-detector and to simplify manufacturing process. The scintillation micro-sized ZWO powder was obtained by solid state synthesis with addition of a mineralizer. The obtaining technology and synthesis process were described in [14]. Synthesized ZWO powder has not such wide particle sizes distribution as crushed crystal powder therefore it was divided into two fractions $80-140 \mu \mathrm{m}$ and $140-280 \mu \mathrm{m}$.

We investigate the dependence of light output on the filler-binder ratio in composites to estimate the best light collection conditions. Samples with different consist of the as-synthesized powder (from 5 wt. $\%$ to 60 wt. $\%$ ) were made. Thickness of samples was $1 \mathrm{~mm}$. The results of light output measurements are presented in Table 3.

The data of Table 3 shows that samples light output value rises with increasing of filler composition. Such trend observed up to 50 wt.\%. The light output value decreases with further increaseing of filler 
Table 3. Light output values of the composites with different consist of as-synthesized by solid state method $\mathrm{ZnWO}_{4}$ powder

\begin{tabular}{|c|c||}
\hline $\begin{array}{c}\text { Sample/filler consist in } \\
\text { sample, wt. } \%\end{array}$ & Light output, \% \\
\hline ZnWO $_{4}$ single crystal & 100 \\
Pure rubber & 8 (noize) \\
5 & 31 \\
10 & 71 \\
20 & 136 \\
30 & 171 \\
40 & 232 \\
50 & 272 \\
60 & 261 \\
\hline
\end{tabular}

concentrations. This is may be related to light collection conditions degradation. Moreover increase of filler consist leads to technological difficulties of the samples making process. Thus, the optimal filler consist in the composite is $40-55 \mathrm{wt} \%$.

The light output values of composite samples with thickness of $1 \mathrm{~mm}$ in comparison with ZWO single crystal $\left(10 \times 10 \times 1 \mathrm{~mm}^{3}\right)$ and composite sample based on as-crushed ZWO crystal (thickness of $1 \mathrm{~mm}$ ) are shown in Table 4.

The light output measurement results showed that the best value demonstrated the sample based on as-synthesized powder - $272 \%$ respectively to ZWO single crystal. This value comparable to the light output value of composite based on as-crushed crystal. Dividing of obtained powder into fraction is inexpedient.

ZEBRA-detector with composite based on as-synthesized ZWO powder was made. The results of its testing are shown in Table 5 .

ZEBRA-detector based on ZWO powders obtained by solid state synthesis demonstrates detection efficiency comparable with efficiency of detectors based on ZWO as-
Table 4. Light output values of the composites based on different fraction of synthesized by solid state method $\mathrm{ZnWO}_{4}$ powder

\begin{tabular}{|c|c|c|}
\hline \hline No. & Samples/fraction, $\mu \mathrm{m}$ & Light output, \% \\
\hline 1 & ZnWO $_{4}$ single crystal & 100 \\
2 & $\begin{array}{c}\text { As-crushed ZWO single } \\
\text { crystal }\end{array}$ & 280 \\
3 & As-synthesized powder & 272 \\
4 & $140-280$ & 173 \\
\hline
\end{tabular}

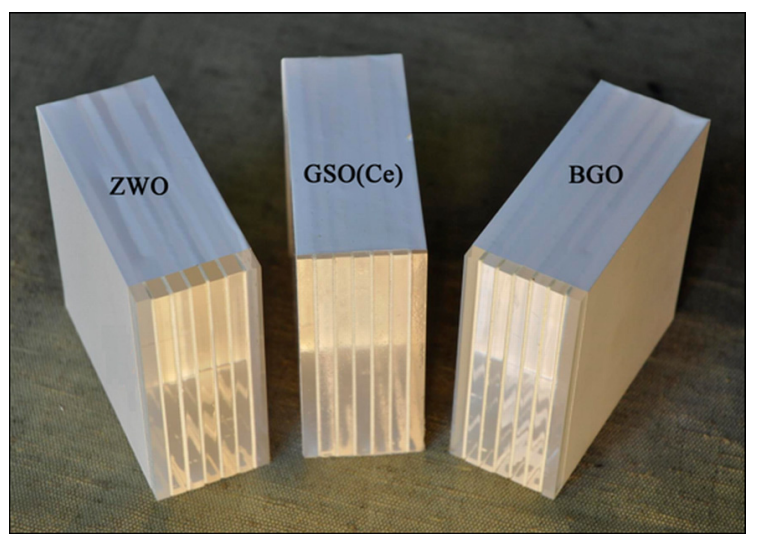

Fig. 2. General view of fabricated ZEBRA-detectors based on scintillators ZWO, GSO(Ce), BGO of sizes $100 \times 100 \times 41 \mathrm{~mm}^{3}$.

crushed crystal and $\mathrm{CdWO}_{4}$ single crystal. In order to increase the ZEBRA-detector sensitivity it's necessary to increase the detector's size, in particular sensitivity area. In general, the multi-layered detector can comprise arbitrary number of plates without area limitations.

\subsection{Features of fast neutrons interaction} with ZEBRA-detector

It is known that in the energy range 0.1-20 MeW one of the most probable mechanisms of neutron interaction with nuclei is reaction of inelastic scattering $(n$, $\left.n^{\prime} \gamma\right)$ with formation of compound nuclei $[22$, 23]. In this reaction, the energy of incident

Table 5. The functional parameters of composite detectors based on dispersed $\mathrm{ZnWO}_{4}$ powders comparable with $\mathrm{CdWO}_{4}$ single crystal (radiative source $-{ }^{252} \mathrm{Cf}$ )

\begin{tabular}{|c|c|c|c|c|}
\hline Composite scintillator & Size, $\mathrm{mm}^{3}$ & $\begin{array}{c}\text { Neutron flux, } \\
\mathrm{nps} \cdot \mathrm{cm}^{-2}\end{array}$ & $\begin{array}{c}\text { Sensitivity, } \eta, \\
\mathrm{cps} / \mathrm{nps} \cdot \mathrm{cm}^{-2}\end{array}$ & Efficiency, $\varepsilon, \%$ \\
\hline $\begin{array}{c}\text { Crystal CdWO } \\
\text { ZWO-ZEBRA }\end{array}$ & $\varnothing 63 \times 100$ & 7.54 & 23 & 53 \\
$\begin{array}{c}\text { (as-crushed crystal) } \\
\text { ZWO-ZEBRA } \\
\text { (solid state synthesis) }\end{array}$ & $40 \times 40 \times 41$ & 3.85 & 8.8 & 55 \\
\hline
\end{tabular}



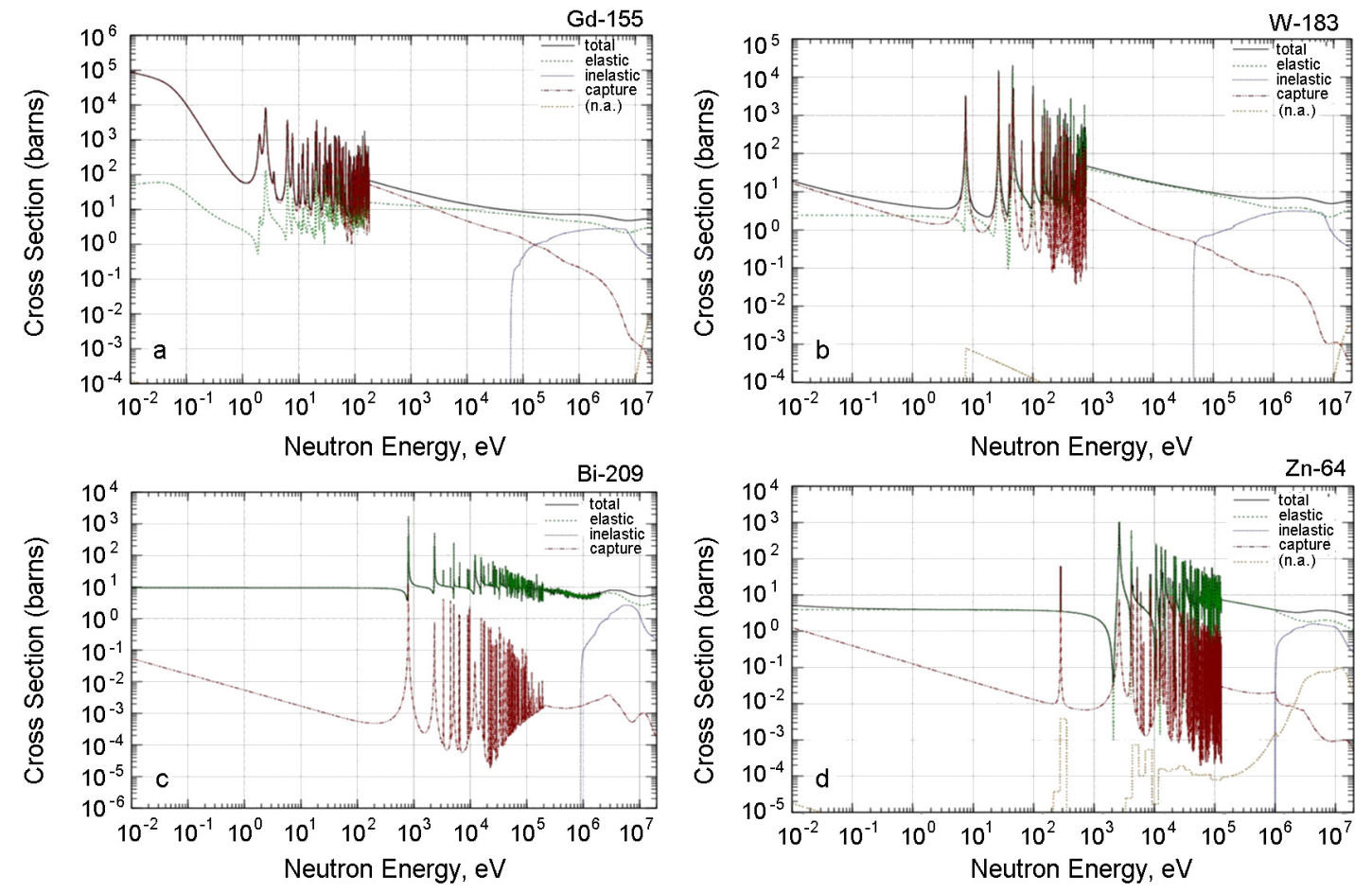

Fig. 3. Radiation capture cross-sections for the resonance effect and thermal neutrons (radiation capture) [25].

neutron goes to excitation of the target nucleus levels and escape of inelastically scattered neutrons.

The angular distribution of inelastic scattering cross section can be described as a sum of isotropic and anisotropic parts, and the anisotropic component represents only about $30 \%$. For this reason, such scattering allows significant change in the direction of neutron travel [24].

As a result, neutrons can move in a direction perpendicular to the incoming direction (with reduced energy) i.e., not along the depth (thickness) of the scintillator, but across the scintillator. For this reason, after a critical thickness is reached, detector sensitivity depends only on its cross-sectional area. Theoretical calculations produced according to [10] give us $L \sim 4.2 \mathrm{~cm}$ for $\mathrm{CdWO}_{4}$. This is in a good agreement with experiment.

Radiation capture cross-sections for the resonance effect and thermal neutrons (radiation capture) were given in [16]. It is very important to put attention, that if for inelastic scattering (main mechanism for interaction fast neutron with single crystal scintillators) capture cross-section not more 2-3 B, for multi-layered composite structure include, due to moderate flux for layer organic plastic this parameter about $400 \mathrm{~B}$ (resonance effect for nucleus W, Gd) and nearly 2500-48000 B (radiation capture for these nucleus) [25].

For this reason at multi-layered structure realize cascade multi-layered process which leads to contributes to much more high efficiency registration fast neutrons (Fig. 1, Table 2).

From the data on parameters of the resonance scattering effect (Fig. 3), it follows that both radiation capture cross-section and its energy are significantly different for different nuclei. Thus, for ZWO the resonance scattering energy for zinc is in the region of $100 \mathrm{keV}$, and for tungsten it is by two orders lower.

Therefore, the probability for a neutron to be decelerated to the energy of radiation scattering on $\mathrm{Zn}$ atoms is much higher than to thermal neutron energies $(W)$. Though the radiation capture cross-section in resonance scattering is much larger for $W$ nuclei, the contribution from $\mathrm{Zn}$ atoms can be significant in this effect. This can explain the deviations from linearity of the dependence of fast neutron detection efficiency on the atomic number of the nucleus, which is noted for zinc tungstate.

Due to the effects of resonance scattering and radiation capture in multi-layered composite detectors, the fast neutron detec- 


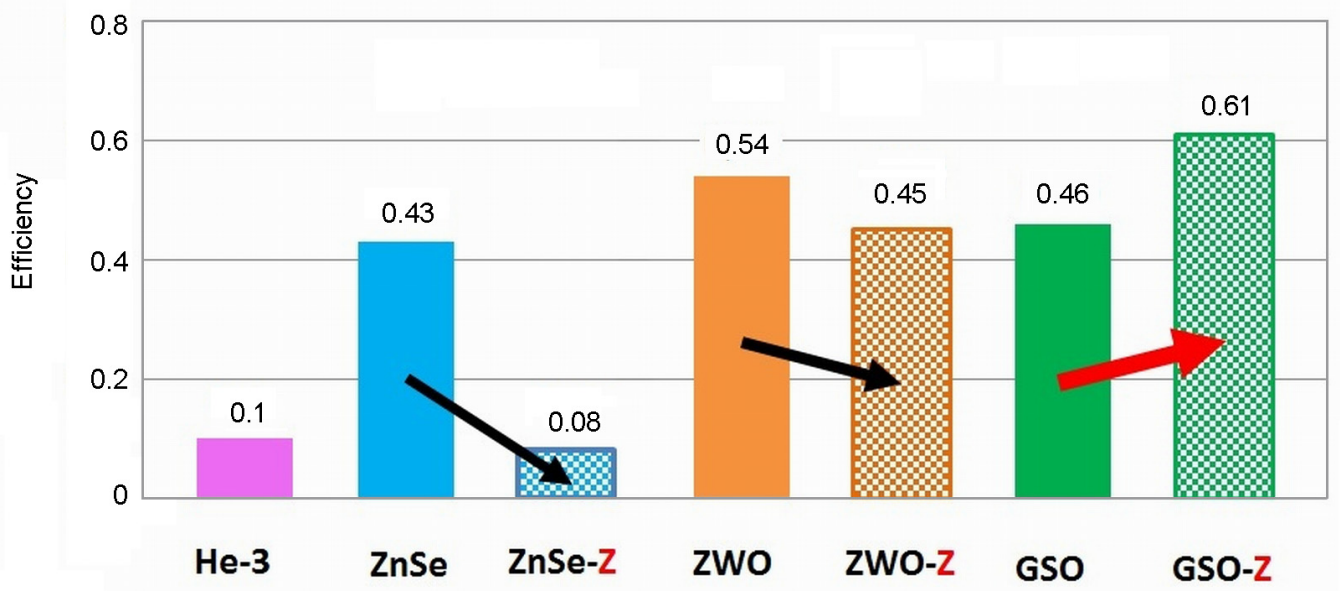

Fig. 4. Changes in the fast neutron detection efficiency when passing from single crystals to ZEBRA composites. ZnSe: Recording of only $\left(n, n^{\prime} \gamma\right)$. ZWO: Recording of $\left(n^{\prime} \gamma\right)+\left(n^{\prime} \gamma\right)_{\text {res }}$. GSO(Ce): Recording of $\left(n^{\prime} \gamma\right)+\left(n^{\prime} \gamma\right)_{r a d}$.

tion efficiency is significantly increases with a relatively small composite thickness. As a result, the sensitivity of such detectors is comparable to detection efficiency and sensitivity of single crystal detectors of much larger thickness (Fig. 4).

The optimum combination of inelastic and elastic scattering mechanisms, as well of radiation capture (in presence of such nuclei as Gd) is possible in the multi-layered ZEBRA-detectors of our development based on heavy-oxide composite scintillators. Despite of much less volume of the active substance (heavy-oxide composite) that records neutrons in such detectors, the efficiency of fast neutron detection reaches 40-50\%, which is practically comparable to detection efficiency of expensive largesized heavy-oxide single crystals. At the same time, detection sensitivity and detection thresholds of hidden special nuclear materials will be substantially better with ZEBRA-detectors. With their sensitivity to fast neutrons $50 \mathrm{cps} /\left(\right.$ neutron $\left.\cdot \mathrm{s}^{-1} \cdot \mathrm{cm}^{-2}\right)$ and higher, they are comparable or superior to ${ }^{3} \mathrm{He}$ counters, but their size and weight are smaller by tens of times.

\section{Conclusions}

It has been shown that registration efficiency of fast neutrons by multi-layered composite ZEBRA-detectors based on heavyoxide scintillators achieved the value about $50 \%$ that is close to this of $\mathrm{CdWO}_{4}$ single crystal detector with the same size. Sensitivity of ZWO-ZEBRA-detector with size of $100 \times 100 \times 41 \mathrm{~mm}^{3}$ is comparable to sensitivity of ${ }^{3} \mathrm{He}$ counter with moderator. ZEBRAdetector based on $\mathrm{ZnWO}_{4}$ crushed crystal is promising for application in the field of homeland security and nuclear safeguards.

$\mathrm{ZnWO}_{4}$ powder obtained by solid state synthesis was proposed as a filler for composite scintillator (detector active layer) making. ZEBRA-detector based on such composite has the values of technical sensitivity and detection efficiency of fast neutrons not lower than those for ZEBRA-detectors based on as-crushed ZWO crystal. Manufacturing process of ZEBRA-detectors with optimal parameters was simplified since this allows to bypassing the single crystal growth stage.

An important feature of the proposed ZEBRA-detector as compared with all the existing ways of replacement of ${ }^{3} \mathrm{He}$ counters by solid-state or gas discharge detectors that can efficiently detect only thermal neutrons ( ${ }^{6} \mathrm{Li}$ and ${ }^{10} \mathrm{~B}$ technologies) is possibility of its using without the massive plastic moderators. In our approach, fast neutrons are detected directly by a heavy-oxide scintillator as single crystal or in multi-layered composite detector, which ensures much higher detection efficiency - up to $50 \%$ and higher sensitivity per unit volume of the detector. As a consequence, the performance of such fast neutron detectors in detection of special nuclear materials, including those hidden inside protecting containers, will be substantially higher.

\section{References}

1. U.S. Patent 8,941,075 (2015).

2. U.K.Akimov, Phys.Part.Nucl., 25, 206 (1994).

3. J.L.Lacy, A.Athanasiades et al., Nucl.Instr. Meth. Phys. Res.:A, 652, 359 (2011). 
4. L.Wanga, J.Jarrella, S.Xuea et al., Nucl. Instr. Meth. Phys. Res.:A, publication online 31 January 2018.

5. L3 Security \& Detection Systems, USA:http://www.sds.1-3com.com .

6. V.N.Marin, P.A.Sadykov, D.N.Trunov et al., Pis'ma v Zh. Eksp. i Teor. Fiziki, 5 (2015).

7. M.K.Singhab, A.Sonayac, M.Deniz, Nucl. Instr. Meth. Phys. Res.:A , 868, 109 (2017) .

8. Rus. Federation Patent 2570588 (2017).

9. U.S. Patent 0272910 (2009).

10. V.D.Ryzhikov, S.V.Naydenov, G.M.Onyshchenko et al., Radiat. Meas., 105, 17 (2017).

11. V.Ryzhikov, S.V.Naydenov, T.Pochet, EPJ Web of Conf. 170, 07010 (2018).

12. P.Buchele, M.Richter, S.C.Tedde et al., $\mathrm{Na}$ ture Photon., 9, 846 (2015).

13. V.D.Ryzhikov, in: Proc. 2015 IEEE Nucl. Sci. Symp. Med. Imaging Conf. (NSS/MIC), San Diego, CA, USA (2015), p.48.

14. Patent Application Ukraine, a201708723 (2017).
15. V.D.Ryzhikov, B.V.Grinyov, G.M.Onyshchenko et al., Functional Materials, 21, 345 (2014).

16. V.D.Ryzhikov, S.V.Naydenov, T.Pochet et al., in: Proc. ANIMMA-2017 Conf., Liege, Belgium, 170 (2017), p.305.

17. V.Ryzhikov, B.Grynyov, G.Onishchenko et al., Telecomm. Radio Eng., 71, 1665 (2012).

18. N.Z.Galunov, O.A.Tarasenko, V.A.Tarasov, Functional Matterials, 22, 61 (2015).

19. N.Z.Galunov, O.A.Tarasenko, V.A.Tarasov, Functional Matterials, 20, 304 (2013).

20. T.E.Gorbacheva, V.A.Tarasov, N.Z.Galunov, Functional Materials, 22, 408 (2015).

21. L.L.Nagornaya, B.V.Grinyov, A.M.Dubovik et al., IEEE Trans. Nucl.Sci., 56, 994 (2009).

22. U.S. Patent 0272910 (2009).

23. Patent of Ukraine 25484A (1998).

24. A.V.Bushuev, Experimental Reactors Physic, MIFI, Moscow (2008) [in Russian].

25. D.P.Taylor, Appl.Chem., 71, 1593 (1999). 